\title{
Mast cells as targets for the therapy of inflammatory bowel disease
}

\author{
Elyse Y Bissonnette, PHD, R Christopher Benyon, PhD, A DeAn BeFus, PhD
}

\begin{abstract}
The etiology and pathogenesis of inflammatory bowel disease (IBD) is poorly understood. However, numerous studies have demonstrated that immunological and inflammatory responses are activated during this disease. A better understanding of these events will help identify appropriate therapeutic interventions. Mast cell hyperplasia is a prominent feature of inflamed intestinal tissue in IBD. Intestinal mast cells are heterogeneous and at least two populations are present in the human intestine. The authors' objective is to explore mast cell properties, activation and mediators that are involved in the induction, maintenance and perpetuation of inflammatory lesions in the intestine. Although some therapies used in IBD can modulate mast cell activities, whether these actions are important in the beneficial effects of the drugs is unknown. Future drug development targeted to the inhibition of mast cells might be of therapeutic value. However, a cascade of different cellular events are involved in IBD development. The complexity of the disease raises difficulties in the development of therapies. Multiple drugs, selective for different phases of the disease or acting on different cells, might be most appropriate, rather than a single, all-encompassing therapeutic agent. Can J Gastroenterol 1990;4(7):285-288
\end{abstract}

Key Words: Inflammation, Mast cells, Therapy

Les mastocytes comme cibles de la thérapie des maladies inflammatoires de l'intestin

RESUME: L'étiologie et la pathogenèse des maladies inflammatoires de l'intestin (MII) restent obscures. Pourtant, de nombreuses études indiquent que les réponses immunologiques et inflammatoires sont déclenchées durant ces affections. Une meilleure compréhension des événements en cause permettra de définir les interventions thérapeutiques appropriées. L'hyperplasie des mastocytes est une caractéristique importante des tissus intestinaux dans les MII. Les mastocytes de l'intestin sont hétérogènes et on relève la présence d'au moins deux populations dans l'intestin de l'humain. Les auteurs se sont proposés d'explorer leurs propriétés, leur activation ainsi que les médiateurs responsables des lésions inflammatoires de l'intestin, de leur maintien et de leur durée. Bien que certains traitements puissent modifier les activités des mastocytes, on ne sait pas si le phénomène explique certains des effets bénéfiques des médicaments. La mise au point de nouvelles substances visant l'inhibition des mastocytes pourrait présenter une certaine valeur thérapeutique. Cependant, toute une chaîne d'événements cellulaires divers participent au développement des MII. La complexité de ces affections rend l'institution de nouvelles thérapies difficiles. Plutôt qu'un seul médicament ou agent thérapeutique global, il serait peut-être plus approprié d'administrer plusieurs médicaments - chacun agissant à différents stades de la maladie ou sur des cellules particulières.

Department of Microbiology and Infectious Diseases, Immunological Sciences Research Group, University of Calgary, Calgary, Alberta

Correspondence and reprints: Dr AD Befus, MID, University of Calgary Health Sciences, 3330 Hospital Drive NW, Calgary, Alberta T2N 4N1. Telephone (403) 220-4560
Aast cells are found 1 throughout the body and are abundant in the skin and gastrointestinal mucosa. Their occurrence in strategic areas, often close to nerves and vasculature, and their capacity to release a variety of potent mediators in response to many inflammatory stimuli contribute to pathological conditions. In the past, mast cells were mainly considered in relation to immunoglobulin $\mathrm{E}$ ( $\mathrm{IgE}$ ) antibody responses, but now it is well recognized that mast cells can be activated by a wide range of factors. Activated mast cells are implicated in many physiological and pathological processes including inflammation, fibrosis, infectious diseases and neoplasia (1-3)

Celiac disease, ulcerative colitis and Crohn's disease are associated with mast cell hyperplasia and activation (4. 6). This hyperplasia might be caused by a local proliferation and/or differentiation, or by chemotaxis of mast cells or their progenitors from distant sites. A recent study showed that mast cells display chemotaxis towards laminin, a major component of basement membranes and inflammation (7). This might explain the accumulation of mast cells at sites of tissue injury where laminin may be exposed, degraded and synthesized. This chemotaxis can be increased when mast cells are stimulated with antigen. It is interesting that intestinal epithelial antigens can stimulate mediator secretion from intestinal mast cells in inflammatory bowel disease (IBD) patients but not from nonIBD patients (8). The role of mast cells in pathogenesis or tissue repair in IBD remains to be clarified, but they appear 
TABLE 1

Heterogeneity of human mast cells

\begin{tabular}{|c|c|c|}
\hline & Skin & Intestine \\
\hline Formalin-sensitive & + & ++ \\
\hline Formalin-insensitive & +++ & + \\
\hline \multicolumn{3}{|l|}{ Mediators } \\
\hline Histamine (pg/cell) & 3-5 & $1-3$ \\
\hline $\begin{array}{l}\text { Proteoglycans } \\
\text { Chondroitin sulphate? }\end{array}$ & Heparin & $\begin{array}{l}\text { Chondroitin } \\
\text { Sulphate F }\end{array}$ \\
\hline \multirow[t]{3}{*}{ Proteases } & Tryptase & Tryptase \\
\hline & Chymase & ? \\
\hline & Carboxypeptidase & ? \\
\hline Eicosanoids & $\mathrm{PGD}_{2}, \mathrm{LTC}_{4}$ & $\mathrm{PGD}_{2}, \mathrm{LTC}_{4} / \mathrm{D}_{4} / \mathrm{E}_{4}$ \\
\hline \multicolumn{3}{|l|}{ Stimuli for histamine release } \\
\hline IgE-dependent & + & + \\
\hline Ionophore A23187 & + & + \\
\hline Compound $48 / 80$ & + & - \\
\hline Morphine, VIP & + & - \\
\hline Somatostatin & + & - \\
\hline Substance P & + & - \\
\hline
\end{tabular}

LT Leukotriene: PG Prostaglandin: VIP Vasoactive intestinal peptide; + Induce histamine secretion:Do not induce secretion: ? Response unknown

to be potentially important therapeutic targets.

\section{MAST CELL HETEROGENEITY AND ACTIVATION}

There are numerous studies on the heterogeneity of mast cells regarding their morphology, function, and mediator content $(9,10)$. In rodents, there are at least two subpopulations of mast cells: connective tissue and mucosal mast cells. The development of techniques to purify each subpopulation in rodents has allowed them to be characterized in detail (9). Heterogeneity is also evident in human mast cells, but unfortunately the two (or more) subpopulations are difficult to separate because of their physical similarities (10).

Subpopulations of human mast cells differ in their sensitivity to formaldehyde blockade of dye binding, as well as their proteoglycan and protease content (Table 1). One subpopulation, abundant in certain connective tissue sites, contains two proteases, tryptase and chymase, whereas the other subpopulation, most abundant at mucosal surfaces contains only tryptase (11). Both populations are present in human intestine; the latter is prominent in the mucosa, whereas the former is prominent in the muscle and connective tissue layers. Further characterization and analysis of human mast cell subpopulations is essential to determine if they are functionally different and to what extent they are similar to the mast cell populations more widely studied in the rat.

Heterogeneity of mast cells is also evident at the functional level (Table 1). There are site-specific differences in the responses of human mast cells to various stimuli. Recent observations of anatomic associations and interactions between peripheral nerves and mast cells in the gastrointestinal tracts of rats and humans may shed new light on site-specific mechanisms of the initiation and modulation of pathogenesis in IBD.

Many inflammatory cells and cytokines are implicated in the development of IBD. Interactions among these cells and mast cells can lead to mast cell activation or down-regulation.

Mast cell activating factors have been identified in macrophages, neutrophils, $T$ lymphocytes and eosinophils. Furthermore, because of their similarities to mast cells and their accessibility, human basophils have been studied for their responsiveness to recombinant cytokines. Only interleukin-3 and granulocyte macrophage colony stimulating factor (GMCSF) stimulated the release of histamine (1). Interleukin-1 beta, $-2,-3,-4,-5$ and -6 , gamma-interferon and tumour necrosis factor (TNF) did not induce histamine secretion from human basophils (1). However, pretreatment of human basophils with gamma-interferon or interleukin-3 augmented IgE-dependent histamine release (12). Thus, given the spectrum of factors which can activate mast cells, it is unclear which mechanism might be most relevant in IBD: allergen-IgE, complement, neuropeptides, cytokines, major basic protein, peroxidase or a combination.

MAST CELL MEDIATORS AND THE PATHOGENESIS OF IBD

Mast cell mediators have a wide range of actions which have been reviewed extensively $(10,11,13)$. Al. though a number of inflammatory mediators have been identified in human intestinal mast cells (Table 1), studies of these cells are still in their infancy. Many of the cell types present in the intestine are targets for mast cell mediators. Consequences of mast cell mediator release could include: vasodilation, increased vascular permeability, activation of sensory nerves (histamine), enhanced mucus and fluid secretion and smooth muscle contraction (histamine, prostaglandin $\mathrm{D}_{2}$, sulfidopeptide leukotrienes); vasoconstriction with resulting ischemic necrosis of mucosa (alpha-TNF, platelet activating factor-acether, leukotriene $\mathrm{C}_{4}$ ); recruitment and activation of neutrophils and eosinophils leading to epithelial damage (polypeptide chemotactic factors, leukotrieneB4, platelet activating factor-acether, histamine, alpha-TNF); changes in neuropeptide (substance $P$, vasoactive intestinal peptide) levels resulting in altered vasomotor function and lymphocyte activity (tryptase and chymase).

Rodent mast cell lines synthesize a variety of cytokines including interleukins $1,3,4,5$ and 6 , gamma-interferon, GMCSF and alpha-TNF (14) which, if released by human intestinal mast cells, would allow them to initiate or modulate diverse immune and inflammatory functions. For example, interleukin-3 and -4 may have autocrine functions as they induce mast cell proliferation, while alpha-TNF, recently identified as a product of human mast cells and/or basophils (15), has multi. ple activities relevant to the develop. 


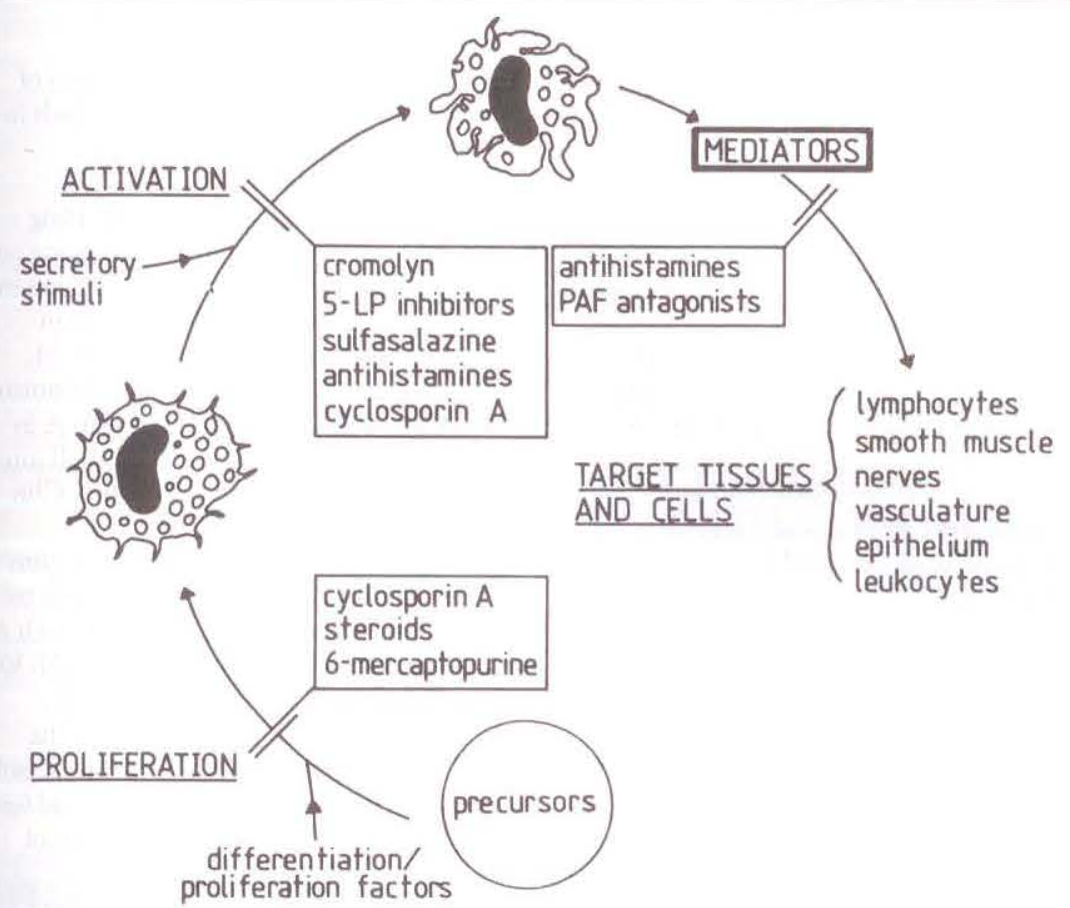

Figure 1) Down-regulation of mast cells by drugs used in the therapy of inflammatory bowel disease. 5-LP 5-Lipoxygenase; PAF Platelet-activating factor

ment of immune and inflammatory responses.

\section{PHARMACOLOGICAL MANIPULATION OF MAST CELL FUNCTION}

Figure 1 illustrates the multiple sites where drugs used to treat intestinal inflammation may down-regulate mast cell function. Several drugs may affect mast cell development and proliferation. Knowledge of human mast cell development is limited, but studies with rodent mast cells demonstrate the importance of the $\mathrm{T}$ lymphocytederived cytokines interleukin- 3 and -4 in the development of mast cells from precursors from bone marrow and other sites (9). These cytokines are probably also required for human mast cell development in association with accessory cells such as fibroblasts (16). Endogenous inhibitors of mast cell proliferation also exist, eg, GMCSF, gamma-interferon and beta-transforming growth factor $(17,18)$.

Corticosteroids reduce the numbers of mast cells in tissues, eg, in the intestine of Nippostrongylus brasiliensis-infected rats where mast cells are markedly depleted within $24 \mathrm{~h}$ of steroid treatment (19). These effects may be due to several actions of corticosteroids such as their abilities to reduce interleukin 3 production by $T$ lymphocytes (20), to act directly on mast cells to inhibit proper granule formation (21), and to stimulate programmed cell death in mast cells and their subsequent phagocytosis by macrophages (personal communication).

The immunosuppressant cyclosporine $\mathrm{A}$ also interferes with the synthesis of cytokines by $T$ lymphocytes, which may account for its inhibition of mast cell development (22). In contrast, inhibitors of DNA synthesis such as 6-mercaptopurine and azathioprine which have had limited trials for treatment of IBD may diminish mastocytosis by a direct effect on mast cell precursors (23).

The multiple pathways involved in mast cell stimulus-secretion coupling have been pharmacologically manipulated. Cromolyn sodium inhibits in vitro $\operatorname{lgE}$-dependent release of histamine and eicosanoids from human lung and intestinal mast cells (24). Sulphasalazine inhibits histamine release from rat and mouse peritoneal mast cells (25) and diminishes rat mast cell cytotoxicity (unpublished observations). Cyclosporine $\mathrm{A}$, in addition to its effects on mast cell development, both down-regulates the expression of genes for inflammatory polypeptides expressed by murine mast cells (14) and inhibits murine histamine release from rat mast cells and human basophils (26).

Products of 5-lipoxygenase action such as leukotriene $B_{4}$ and sulfidopeptide leukotrienes may play a role in IBD: 5-lipoxygenase inhibitors prevent several of the pathological changes in animal models of IBD (27). The 5 . lipoxygenase pathway in human mast cells is susceptible to one such inhibitor, termed AA-861 (28). Although many cell types produce 5-lipoxygenase products, the effect of 5-lipoxygenase inhibitors on mast cells resident in human intestine could contribute to their potential clinical use.

Antagonists of mast cell mediators may also be employed therapeutically. While antihistamines directly block the effects of histamine on target tissues, several of these compounds also inhibit mediator release from human mast cells (29). Human intestinal mast cells may be a source of platelet activating factor-acether (30), and antagonists of this lipid mediator show promise for therapy of IBD in clinical trials and animal models.

Although this section has concentrated on mast cells as targets for therapeutic agents, the drugs mentioned affect the functions of various cell types. For example, cromolyn sodium down-regulates the activities of monocytes, eosinophils, macrophages, platelets and neutrophils. Similarly, by affecting the release of cytokines from $T$ lymphocytes, corticosteroids and cyclosporine A will have complex effects on many aspects of immune and inflammatory systems which depend on these cytokines.

\section{FUTURE DIRECTIONS}

It is likely that mast cells play important roles in IBD, eg, in motility changes, diarrhea, inflammation, tissue damage and repair. Techniques to study 
the properties and functions of mast cells in different compartments of the human intestine must be improved to facilitate understanding of their roles in intestinal injury, repair and normal function. Further characterization of responses of human mast cell subpopulations to different therapeutic agents will be important in understanding the actions of existing therapies and in the development of new ones.

ACKNOWLEDGEMENTS: The authors are grateful to the Medical Research Council of Canada, the Alberta Heritage Foundation for Medical Research and Fond de la Recherche en Santé du Québec for providing personnel and operating support.

\section{REFERENCES}

1. Lett-Brown MA, Alam R, Grant JA. Regulation of human basophils and mast cells. Activation by cytokines. In: Cruse JM, Lewis RE Jr, eds. The Year in Immunology 1988. Immunoregulatory Cytokines and Cell Growth. Basel: Karger, 1989:195-204.

2. Galli SJ, Austen KF. Mast Cell and Basophil Differentiation and Function in Health and Disease. New York: Raven Press, 1989.

3. Holgate ST. Mast Cells, Mediators and Disease. Boston: Kluwer Academic Publishers, 1988.

4. Balazs M, Illyes G, Vadasz G. Mast cells in ulcerative colitis. Quantitative and ultrastructural studies. Virchows Arch Cell Pathol 1989;57:353-60.

5. Dvorak AM, Monohan RA, Osage JE, Dickersin GR. Crohn's disease transmission electron microscopic studies. Immunologic inflammatory response. Alteration of mast cells, basophils, eosinophils, and microvasculature. Hum Pathol 1980;11:606-19.

6. Strobel S, Busuttil A, Ferguson A. Human intestinal mucosal mast cells: Expanded population in untreated coeliac disease. Gut 1983;24:222-7.

7. Thompson HL, Burbelo PD, Yamada Y, Kleinmam HK, Metcalfe DD. Mast cells chemotax to laminin with enhancement after $\mathrm{lgE}$-mediated activation. J Immunol 1989;143:4188-92.

8. Fox CC, Lichtenstein LM, Roche JK.
Immediate hypersensitivity responses in idiopathic inflammatory bowel disease (IBD): Histamine release from human intestinal mucosal mast cells (MC) in response to gut epithelial antigens. Gastroenterology 1987;92:1394.

9. Kitamura Y. Heterogeneity of mast cells and phenotypic change between subpopulations. Annu Rev Immunol 1989;7:59-76.

10. Benyon RC, Lowman MA, Rees PH, Holgate ST, Church MK. Mast cell heterogeneity. In: Morley J, ed. Asthma Reviews, Vol 2. London: Academic Press, 1989:151-89.

11. Schwartz LB. Preformed mediators of human mast cells and basophils. In: Holgate ST, ed. Mast Cells, Mediators and Disease. Boston: Kluwer Academic Press, 1988:129-47.

12. Schleimer RP, Derse CP, Friedman B, et al. Regulation of human basophil mediator release by cytokines. I. Interaction with antiinflammatory steroids. J Immunol 1989;143:1310-7.

13. Caughey GH. Roles of mast cell tryptase and chymase in airway function. Am J Physiol 1989;257:L39-46.

14. Burd PR, Rogers HW, Gordon JR, et al. Interleukin 3-dependent and -independent mast cells stimulated with $\operatorname{lgE}$ and antigen express multiple cytokines. J Exp Med 1989;170:245. 57.

15. Sreffen M, Abboud M, Potter GK, Yung YP, Moore MAS. Presence of tumour necrosis factor or a related factor in human basophil/mast cells. Immunology 1989;66:445-50.

16. Furitsu T, Saito H, Dvorak AM, et al. Development of human mast cells in vitro. Proc Natl Acad Sci USA 1989;86:10039-43.

17. Broide DH, Wasserman SI, AlvaroGarcia J, Zvaifler NJ, Firestein GA. Transforming growth factor $-\beta$ selectively inhibits IL-3 dependent mast cell proliferation without affecting mast cell function or differentiation. J lmmunol 1989;143:1591-7.

18. Huff TF, Justus DE. Mast cell differentiation in cultures of $T$ cell-depleted mesenteric lymph nodes from Nippostrongylus brasiliensis-infected mice. Int Arch Allergy Appl Immunol 1988;85:137-44.

19. King SJ, Miller HR, Newlands GF, Woodbury RG. Depletion of mucosal mast cell protease by glucocorticoids: Effect on intestinal anaphylaxis in the rat. Proc Natl Acad Sci USA 1985;82:1214-8

20. Culpepper JA, Lee F. Regulation of IL-3 expression by glucocorticoids in cloned murine T-lymphocytes. J Immunol 1985;135:3191-7.

21. McMenamin CC, Gault EA, Haig DM. The effect of dexamethasone on growth and differentiation of bone-marrow derived mucosal mast cells in vitro. Immunology 1987;62:29-34.

22. Cummins AG, Labrooy JP, Shearman DJC. The effect of cyclosporin A in delaying maturation of the small intestine during weaning in the rat. Clin Exp Immunol 1989;75:451-6.

23. Butterfield JH, Weider DA. In vitro sensitivity of immature mast cells to chemotherapeutic agents. Int Arch Allergy Appl Immunol 1989;89:297-300.

24. Befus AD, Dyck N, Goodacre R, Bienenstock J. Mast cells from the human intestinal lamina propria. Isolation, histochemical subtypes, and functional characterization. J Immunol 1987;138:2604-10.

25. Barrett KE, Tashof TC, Metcalfe DD. Inhibition of $\operatorname{lgE}$-mediated mast cell degranulation by sulphasalazine. Eur ] Pharmacol 1985:107:279-81

26. Pedersen C, Permin H, Stahl Skov P, et al. Inhibitory effect of cyclosporin A on histamine release from human leukocytes and rat mast cells. Allergy 1985;40:103-7.

27. Wallace JL, MacNaughton WK, Morris GP, Beck P. Inhibition of leukotriene synthesis markedly accelerates healing in a rat model of inflammatory bowel disease. Gastroenterology 1989;96:29-36.

28. Cohan V, McKenzie-White J, Triggiani M, Massey W, KageySobotka A, Lichtenstein LM. Heterogeneity of human mast cells and basophils. Effects of a putative 5 . lipoxygenase inhibitor. Biochem Pharmacol 1989;38:4455-9.

29. Lau HYA, Pearce FL. Effects of antihistamines on isolated human lung mast cells, basophil leucocytes and erythrocytes. Agents Actions 1989;27:83-5.

30. Eliakim R, Karmeli F, Razin E, Rachmilewitz D. Role of platelet-activating factor in ulcerative colitis. Enhanced production during active disease and inhibition by sulfasalazine and prednisolone. Gastroenterology 1988;95:1167-72. 


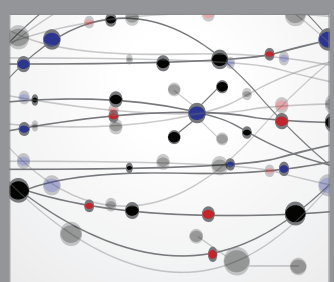

The Scientific World Journal
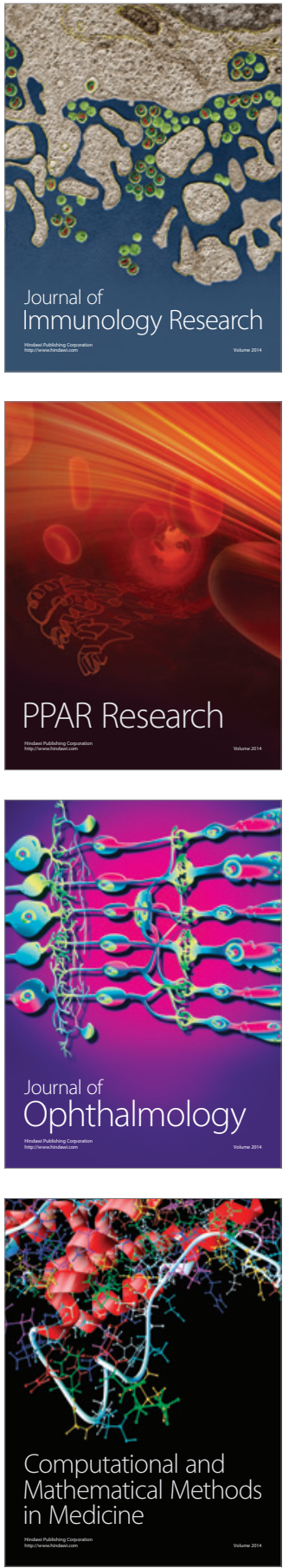

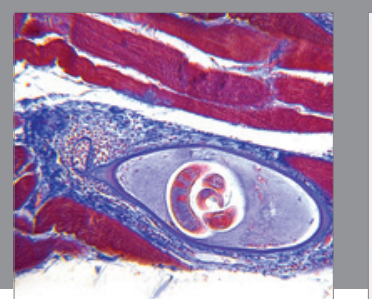

Gastroenterology Research and Practice

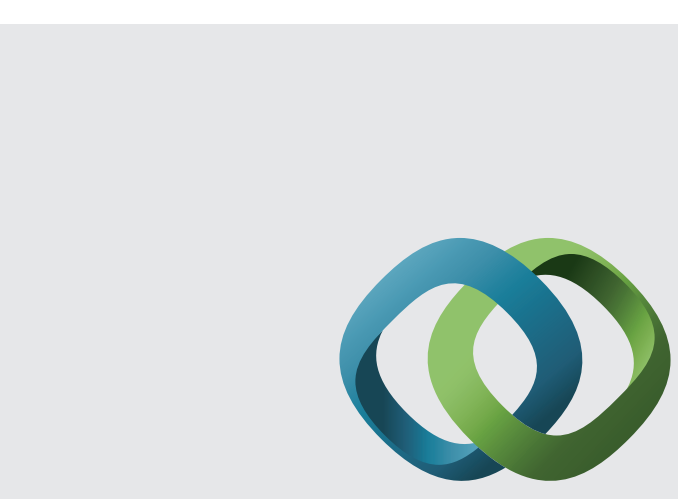

\section{Hindawi}

Submit your manuscripts at

http://www.hindawi.com
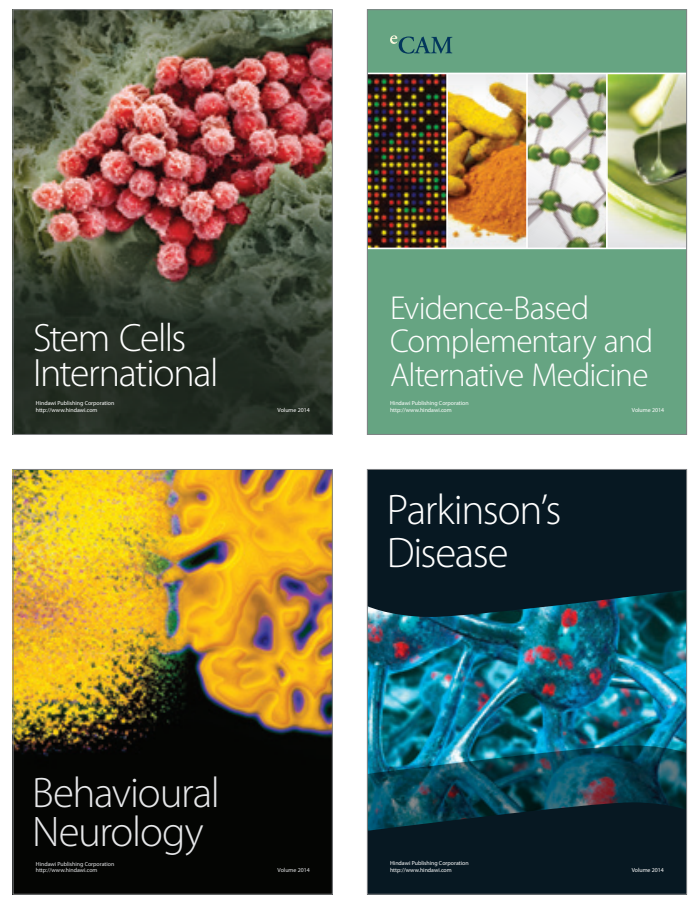
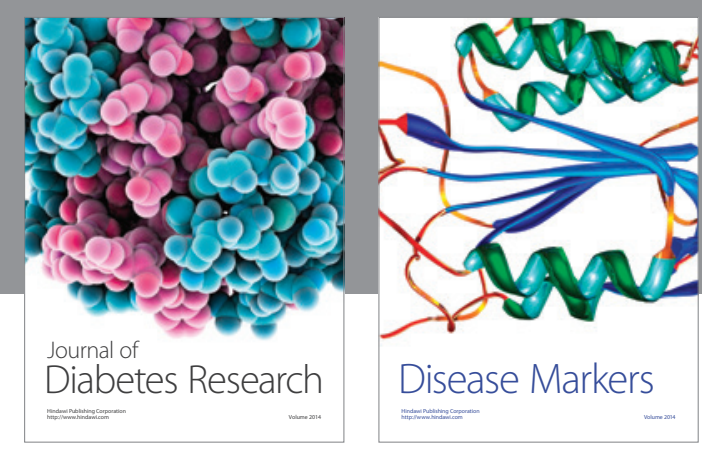

Disease Markers
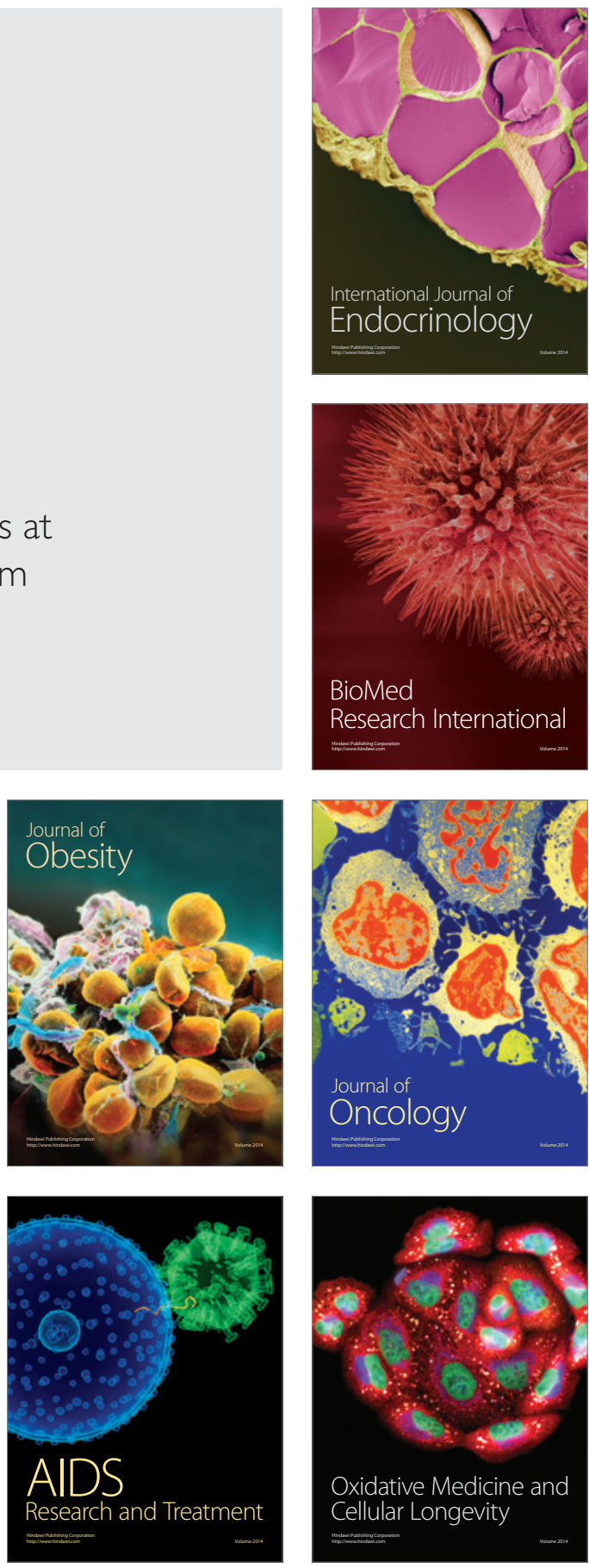